Медицкий І.Б.

$\overline{\text { this type of responsibility; 2) organizational aspect - a system of measures aimed at }}$ implementing measures of constitutional legal responsibility.

In Ukraine, there is a problem of both regulatory support and the implementation of organizational foundations in this area. That is why the problem of legal consolidation and implementation of the legal liability mechanism in Ukraine is relevant and practically significant.

In connection with all of the above, the article is devoted to the essential and functional aspects of the implementation of constitutional responsibility in Ukraine.

According to the author, the mechanism for the implementation of constitutional legal responsibility is a set of interrelated normative, institutional, functional and ideological elements (autonomous subsystems), with the help of which the conscious use of their rights, fulfilment of obligations, compliance with prohibitions, and in the case of constitutional legal tort - the application of constitutional legal sanctions in order to ensure constitutional legality, discipline and the rule of law.

The author also substantiates that, in our opinion, the following are the signs of the mechanism for implementing constitutional legal responsibility: 1) it is a set of interrelated normative, institutional, functional and ideological elements (autonomous subsystems) 2) is aimed at ensuring the conscious use of constitutional legal relations by subjects (in vol. Ch. And state-power and state-political relations) of their rights, fulfilment of duties, compliance with prohibitions, which ensures the implementation nation, first of all, their positive (perspective) constitutional responsibility; 3 ) in the event that the above-mentioned entities commit constitutional law tortes, it is aimed at incarnating their negative (retrospective) constitutional responsibility in the form of constitutional legal sanctions; 4) the ultimate goal of the mechanism for implementing the constitutional legal responsibility of subjects of constitutional legal relations (including Ch. And state-power and state-political relations) is to ensure constitutional legality, discipline and law and order in their activities and in the constitutional relations of which they are subjects.

Keywords: responsibility, social responsibility, legal responsibility, constitutional responsibility, constitutional legal responsibility, mechanism, social mechanism, constitutional legal responsibility mechanism.

\title{
Медицький I.Б.
}

\section{ГУМАНІТАРНІ ТА СОЦІАЛЬНО- ЕКОНОМІЧНІ НАСЛІДКИ АВТОМОБІЛІЗАЦІЇ В УКРАЇНІ: КРИМІНОГЕННИЙ АСПЕКТ}

\author{
УДК 343.9
}

https://doi.org/10.15330/apiclu.50.62-76

Постановка проблеми. Сучасний рівень кримінологічної теорії у частині наслідків злочинності не відповідає суспільній значущості проблеми та пов 'язаним з нею практичним потребам. 
Хоча останнім часом, як вітчизняні, так і зарубіжні науковці, усе частіше звертаються у своїх пошуках до цієї фундаментальної проблеми кримінологічної науки [7, с.169].

Протягом останніх десятиліть у світі спостерігається стрімке зростання кількості транспортних засобів та підвищення інтенсивності дорожнього руху, що призводить до збільшення кількості дорожньо-транспортних пригод (надалі по тексту - ДТП) та їх негативних наслідків. За даними Всесвітньої організації охорони здоров'я, дорожньо-транспортний травматизм на сьогодні $\epsilon$ однією із найбільших проблем охорони здоров'я. За прогнозами, у 2030 р. дорожньо-транспортні пригоди можуть стати однією 3 основних п'яти причин смертності людей у світі. В Україні рівень смертності та травматизму унаслідок ДТП с одним із найвищих в Свропі, а рівень організації безпеки дорожнього руху залишається украй низьким, про що у своїх звітах неодноразово наголошували експерти ВО03, Світового банку та інших міжнародних інституцій.

Аналіз останніх досліджень і публлікацій. Кримінологічна характеристика злочинів проти безпеки руху та експлуатації транспорту загалом та автотранспортних злочинів, зокрема; проблемні моменти їх кримінально-правової кваліфікації виступали предметом досліджень А.М. Бабенко, Д.В. Горшкова, В.В. Ємельяненко, В.А. Звіряки, Ю.Ф. Іванова, В.А. Мисливого, Б.Ф. Мицака, О.М. Мойсюка, А.В. Піддубної, К.О. Полтави, Р.В. Щупаківського та ін. Водночас, питання наслідків автотранспортної злочинності, що уособлюють суспільну небезпечність вказаного різновиду та $\epsilon$ відповідним інформаційним базисом ефективної кримінологічної (у частині припинення і запобігання злочинності) та кримінально-правової (у частині криміналізації / декриміналізації злочинів) політик 3'ясований у недостатньому обсязі.

Стаття має за мету розкрити гуманітарні та соціально-економічні наслідки автомобілізації в Україні у контексті їх криміногенності та «ціни» для суспільства, а також, на основі відповідних узагальнень, 3'ясувати стан судового правозастосування у цій площині. 
Медицкий І.Б.

Виклад основного матеріалу. Міжнародне співтовариство приділяє значну увагу розробці та здійсненню стратегічних заходів із безпеки дорожнього руху, спрямованих на запобігання дорожньо-транспортному травматизму. Зокрема, ГА ООН 02.03.2010 р. прийнято резолюцію № 64/255 «Підвищення безпеки дорожнього руху в усьому світі», співавторами якої стали 69 країн-членів та до реалізації якої долучилася також Україна. Резолюцією проголошено 2011-2020 роки Десятиліттям дій з безпеки дорожнього руху.

Масштабність проблеми та необхідність активізації зусиль у даному відношенні зафіксовано, у тому числі, у Стратегії підвищення рівня безпеки дорожнього руху в Україні на період до 2020 року (розпорядження КМ України від 14.06.2017 р. №481p), Державній програмі підвищення рівня безпеки дорожнього руху в Україні на період до 2020 року (постанова КМ України від 25.04.2018 р. № 435).

Аналіз даних про стан злочинності 2005-2012 рр. засвідчує, що в країні щорічно вчинялося близько 13 тис. злочинів у сфері безпеки дорожнього руху та експлуатації транспорту, що становить 3,1\% від усієї зареєстрованої злочинності. За вказаний період постраждало понад 100 тис. осіб, з яких загинуло 25436 [2, c. 192].

За 2011-2016 роки в Україні зареєстровано близько 170,8 тис. ДТП з постраждалими, у яких загинуло 26,7 тис. та травмовано 210,4 тис. осіб. У 2016 р. зафіксовано зростання кількості ДТП на $5,1 \%$ та травмованих у них осіб на $6,4 \%$ порівняно з 2015 роком. Понад 42,6\% загиблих у 2016 р. були пішоходами та велосипедистами. За останній шестирічний період на дорогах України загинуло 1,4 тис. дітей віком до 18 років, а дорожньо-транспортні пригоди в Україні є першою за поширеністю причиною смерті молоді віком від 15 до 24 років та другою за поширеністю причиною смерті дітей віком від 5 до 14 років. За питомими показниками аварійності та наслідків дорожньо-транспортних пригод Україна також є одним 3 лідерів серед європейських країн. Так, у середньому в країнах - членах ЄС (за даними 2015 р.) на 100 тис. жителів припадає 5,1\% загиблих у дорожньо-транспортних 
пригодах, на 100 тис. транспортних засобів - 8 загиблих, тоді як в Україні такі показники становлять (за даними 2016 р.) відповідно 8 і $22,1 \%$ осіб [12].

Більш предметне уявлення про гуманітарні наслідки дорожньо-транспортного травматизму, характеристику потерпілих від кримінальних правопорушень у сфері безпеки дорожнього руху та експлуатації транспорту осіб, динаміку формує наступна статистична інформація судових і правоохоронних органів:

- Генеральної прокуратури України [4]:

- Патрульної поліції України (обліковано і адміністративні правопорушення - I.M.) [11]:

- судів першої інстанції (за розглядом матеріалів кримінального провадження) [5]:

Наведені дані вирізняс певна фрагментарність та розпорошеність, зумовлена об' сктивними чинниками (до прикладу, лише із 20.11.2012 р. розпорядником статистичної інформації стосовно зареєстрованих злочинів виступає Генеральна прокуратура України, Патрульна поліція України розпочала роботу 04.07.2015 р.).

Таблиця № 1

\begin{tabular}{|c|c|c|c|c|c|}
\hline \multicolumn{6}{|c|}{ Відомості про осіб, які потерпілн від крнмінальних правопорушень } \\
\hline \multirow{2}{*}{ Piк } & $\begin{array}{c}\text { Загальна } \\
\text { кількість }\end{array}$ & Загннуло & $\begin{array}{c}\text { 0сіб } \\
\text { жіночої } \\
\text { статі }\end{array}$ & Неповнолітніх & $\begin{array}{c}\text { Малолітніх } \\
\text { (дітей до 14 } \\
\text { років) }\end{array}$ \\
\cline { 2 - 5 } & \multicolumn{6}{|l|}{ Динаміка до попереднього року (\%) } & & & \\
\hline 2013 & 13610 & 2536 & 4853 & 607 & 510 \\
\hline 2014 & $12430(-8,7 \%)$ & $2559(+0,9 \%)$ & 4171 & 549 & 438 \\
\hline 2105 & $12430(0 \%)$ & $2481(-3,0 \%)$ & 4268 & 573 & 490 \\
\hline 2016 & $12833(+3,2 \%)$ & $2417(-2,6 \%)$ & 4361 & 551 & 522 \\
\hline 2017 & $12088(-5,8 \%)$ & $2395(-0,9 \%)$ & 4156 & 516 & 552 \\
\hline 2018 & $10260(-15,1 \%)$ & $2150(-10,2 \%)$ & 3610 & 386 & 500 \\
\hline
\end{tabular}


Медицкий І.Б.

До них також слід ставитися із певним ступенем критичності, оскільки останні не відображають реального обсягу втрат для

Таб̆лиця № 2

\begin{tabular}{|c|c|c|c|c|}
\hline \multirow[t]{3}{*}{$\mathrm{Pik}$} & \multirow[t]{2}{*}{ Усього ДТП $_{\text {сы }}$} & \multicolumn{3}{|c|}{ ДТІ з постражда.ими } \\
\hline & & усього 0 & загинуло & травмовано \\
\hline & \multicolumn{4}{|c|}{ Динаміка до попереднього року (\%) } \\
\hline 2016 & 158776 & 26782 & 3410 & 33613 \\
\hline 2017 & $162526(+2,4 \%)$ & $27220(+1,6 \%)$ & $3432(+0,6 \%)$ & $34677(+3,2 \%)$ \\
\hline 2018 & $150120(-7,6 \%)$ & $24294(-10,7 \%)$ & $3350(-2,4 \%)$ & $30884(-10,9 \%)$ \\
\hline
\end{tabular}

українсыкого суспільства (людських, ресурсних) від злочинних порушень правил поведінки відповідними суб' єктами. Приміром,

Табллиця № 3

\begin{tabular}{|c|c|c|c|c|c|c|c|}
\hline \multicolumn{8}{|c|}{$\begin{array}{l}\text { Відомості про потерпілнх (Злочнни проти безпекн руху та експлуатації транспорту, } \\
\text { ст.ст. } 276-292 \text { КК України) }\end{array}$} \\
\hline \multirow[t]{2}{*}{ Pik } & \multicolumn{2}{|c|}{$\begin{array}{c}\text { Кількість } \\
\text { потерпілнх }\end{array}$} & \multicolumn{3}{|c|}{$\begin{array}{l}\text { Кількість фізнчних осіб́, якнм } \\
\text { заподіяно шкодн }\end{array}$} & \multirow{2}{*}{$\begin{array}{c}\text { Кількість } \\
\text { юрндичних } \\
\text { осіб, якнм } \\
\text { заподіяно } \\
\text { шкоду }\end{array}$} & \multirow{2}{*}{$\begin{array}{c}\text { Моральної та } \\
\text { матеріальної } \\
\text { шкодн } \\
\text { (усього, грн.) }\end{array}$} \\
\hline & чоловіки & жінкн & життю & здоров 'ю & $\begin{array}{c}\text { матеріальної } \\
\text { та моральної } \\
\text { шкоди }\end{array}$ & & \\
\hline 2014 & 4338 & 2230 & 653 & 2436 & 3479 & 270 & 114406266 \\
\hline 2015 & 3948 & 2010 & 589 & 1877 & 3492 & 152 & 134760311 \\
\hline 2016 & 3721 & 1849 & 579 & 1764 & 3227 & 167 & 130103613 \\
\hline 2017 & 3650 & 1903 & 614 & 1915 & 3024 & 126 & 347936323 \\
\hline 2018 & 3256 & 1894 & 566 & 1990 & 2594 & 110 & 129984817 \\
\hline
\end{tabular}

затверджений постановою КМ України від 30.06.2005 p. (№538) Порядок обліку дорожньо-транспортних пригод, який визначав процедуру їх єдиного обліку та був обов'язковий для виконання на всій території України, втратив чинність на підставі постанови КМ України від 30.03.2016 р. (№252). Відповідно, правоохоронні органи протягом тривалого строку не виконували обов'язків із ведення загальнодержавного обліку ДТП, метою якого було одержання об'єктивних статистичних даних для оцінки стану аварій- 
ності на дорогах України, аналізу причин виникнення цих пригод і вжиття заходів до їх запобігання. Ситуація змінилася лише із затвердженням 22.05.2019 р. нової редакції Правил ведення обліку дорожньо-транспортних пригод (постанова КМ України № 424).

Протягом тривалого часу, через відсутність синхронізації із медичними закладами інформації про ДТП та постраждалих у них осіб, указані дані не потрапляли до відомчої статистики правоохоронних органів. Наслідком чого є суттєві розбіжності iз даними MO3 України, Державної служби статистики України, які, за окремими оцінками, сягають 50\% [10].

Висловлені рекомендації щодо необхідності обрахунку загального обсягу втрачених років потенційного життя через передчасну смертність від ДТП в Україні, уніфікації підходів до розрахунку економічного збитку від втрати життя та розроблення єдиної методології оцінки втрат держави згідно міжнародних стандартів є вкрай актуальними [8], однак наразі їх реалізація залишається ініціативою здебільшого науковців та активних громадських інституцій.

Науковцями Інституту демографії та соціальних досліджень імені М. Птухи НАНУ проведено дослідження масштабу смертності у ДТП, а також обсягу втрачених років потенційного життя. На підставі отриманих розрахунків, у 2015 р. усі смертні випадки, пов'язані з транспортом, стали причиною втрат років потенційного життя, які можна оцінити у 108,74 тис. людино-років (у 2013 p. - 128,18 тис.). Переважна більшість смертей - результат загибелі у автодорожній пригоді, на частку нещасних випадків, пов'язаних із залізничним, повітряним, водним або космічним транспортом, припадають лише поодинокі смерті. Загальна кількість втрачених років потенційного життя чоловіків учетверо вища, ніж жінок, формуючи, при цьому, $80 \%$ усіх втрат. Понад половина $(56 \%)$ смертей до досягнення 65 років припадала у 2015 р. на інтервал 20-44 роки. Наступна конвертація цих втрат у економічному еквіваленті показала, що розрахована величина ВВП, недоотриманого внаслідок передчасної смертності населення України в дорожньо-транспортних пригодах, становила у 2015 р. 5 млрд. грн., або більш як 230 млн. дол. США [15]. 
Медицкий І.Б.

Соціально-економічні наслідки. За даними Світового банку, збитки економіки від ДТП складають 1,5-2,5\% ВВП України, а сукупні річні збитки становлять 4,5 мільярди доларів [14].

Експертами Національної програми 3 попередження дорожньо-транспортного травматизму дітей та молоді «Traffic Challenge», проведено глобальне дослідження оцінки вартості життя та сукупних збитків від ДТП (за статистичними даними 2015 року), з використанням відповідної методики:

1) перший підхід - обрахунок економічних втрат і витрат держави, який базується на офіційних даних та обрахунку збитків, недоотриманих доходів держави. Серед прямих витрат виділяються витрати лікарень на лікування потерпілих, виплата пенсій, одноразові виплати на поховання загиблих, збитки служби з експлуатації доріг від ліквідації наслідків ДТП, витрати Управління безпеки дорожнього руху, Національної поліції і юридичних органів на розслідування ДТП. До непрямих витрат віднесено податки, недоотримані державою у період непрацездатності працівників, недоотримане ВВП, витрати підприємств, співробітники яких потрапили в ДТП, втрати членів сім'ї людини у вигляді недоотриманого доходу. За першим методом вартість життя складає 79618 дол. США (або 1736458 грн.), а загальний річний збиток держави складає 485 млн. долар. США (або 10 млрд. 583 грн., 0,53\% ВВП);

2) другий підхід - обрахунок економічних втрат та витрат держави і домогосподарств, який базується на офіційних даних, обрахунку збитків, недоотриманих доходів держави, витрат домогосподарств (витрати внаслідок передчасної смерті (недоотримане ВВП, пенсії особам, які були на утриманні померлого; а також витрати домогосподарств у вигляді недоотриманої зарплатні протягом потенційного життя) або травматизму (держава виплачує лікарняні, недоотримує ВВП протягом лікування потерпілого; витрати домогосподарств обраховувались у вигляді витрат на лікування). За другим методом вартість життя складає 177 тис. 108 дол. США (аб̆о 3862721 грн.) загальний річний збиток держави складає 1 млрд. 197 дол. США (або 26 млрд. 113 грн., 1,32\% ВBП); 
3) третій підхід - обрахунок соціально-економічних збитків за валовим методом, або європейський обрахунок, який базується на оціночних даних усіх витрат (держави, домогосподарств, моральних збитків). Складовими компонентами виступали: фактичний матеріальний збиток (вартість ремонту автомобіля), адміністративні витрати (вартість пошкодження автомобільної дороги, витрати поліції), медичне обслуговування (надання першої допомоги, виїзд швидкої на місце ДТП, вартість госпіталізації, подальше перебування в лікарні, витрати на хірургію тощо), витрати на ритуальні послуги у випадку смертельних ДТП, людські витрати (біль, горе, страждання). За третім методом вартість життя українця становить 400 тис. 378 дол. США (10 490840 грн.), а загальний економічний збиток від ДТП - 2 млрд. 074 дол. США (або 45 млрд. 227 грн., 2,5\% ВВП) [9].

А.А. Безуглий пропонує, при визначенні загальної величини соціально-економічних втрат від ДТП враховувати як прямі, так і непрямі народногосподарські втрати. До прямих витрат, науковець, зокрема, відносить: збитки власників рухомого складу автомобільного транспорту; збитки служби з експлуатації доріг від ліквідації наслідків ДТП; витрати ДАІ і юридичних органів на розслідування ДТП; витрати медичних закладів на лікування потерпілих; витрати підприємств, співробітники яких стали жертвами аварій (оплата бюлетенів, видача допомоги); витрати державних органів соціального забезпечення (пенсії) і страхові виплати. Непрямі втрати утворюють втрати народного господарства внаслідок тимчасового або повного вибуття людини зі сфери матеріального виробництва, порушення виробничих зв'язків $і$ моральні втрати. Соціально-економічні втрати від ДТП, на його думку, включають у себе втрати від загибелі та поранення людей; збитки від пошкодження транспортних засобів; збитки від псування вантажу; збитки від пошкодження автомобільної дороги

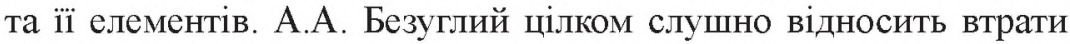
від загибелі та поранення людей до найбільшої частини втрат від ДТП, включаючи до них наступні соціально-економічні показники: економічні втрати через вибуття людини зі сфери виробництва; соціально-економічні втрати держави при виплаті пенсій по інвалідності та у разі втрати годувальника, а також при оплаті 
Медицкий І.Б.

лікування у лікарнях і тимчасової непрацездатності; соціально-економічні втрати через загибель дітей [1, с.231].

Автори праці «США: злочинність та політика» відзначали, що у відношенні до вбивств збитки вираховуються на основі середнього заробітку, віку потерпілих та середньої тривалості життя американця [6, с.243]. Запропонований алгоритм підставно застосувати й до вітчизняних даних кримінальної статистики, з'ясувавши, у тому числі, економічний розмір втрат у результаті позбавлення життя потерпілих від автотранспортних деліктів осіб. При цьому, варто погодитися із Л.В. Кондратюком та В.С. Овчинським, які пропонують враховувати не середній заробіток жертви, а різницю між ВВП на душу населення та фактичним споживанням [6, с.245].

Вихідні дані для підрахунку (2018 рік):

$\mathrm{t}$ - середня тривалість життя (обидві статі) - 71 рік $[13$, с.56];

В - номінальний ВВП у розрахунку на одну особу - 84190 грн. [3];

С - фактичне кінцеве споживання у розрахунку на одну особу (за рік) - 75627 грн. [3];

t2 - середній вік жертв злочинів. Статистичні дані Генеральної прокуратури надмірно не деталізують кримінологічно значиму інформацію про вік потерпілих від злочинної поведінки осіб, виділяючи критерії: повнолітні/неповнолітні/малолітні особи; особи похилого віку. Дані Державної судової адміністрації характеризують повнолітніх та неповнолітніх потерпілих від злочинів, хоча більшою мірою вони орієнтовані на особу злочинця: у частині притягнутих до кримінальної відповідальності та видів кримінального покарання; складу засуджених, у тому числі неповнолітніх.

Узагальнення вироків у справах за статтями 286, 135 КК України, кваліфікованими ознаками яких є заподіяння смерті одному чи декільком потерпілим (СДРСР, 50 вироків, 2017-2019 рр.) дало можливість автору встановити середній вік їх жертв: 2017 р. - 44 роки, 2018 р. - 40 років, 2019 р. -41 рік;

$\mathrm{N}$ - кількість загиблих від злочинів осіб: згідно даних Генеральної прокуратури України у 2018 р. від ДТП загинуло 2150 ociб [4] 
Арифметичним шляхом можна вирахувати втрати для суспільства у зв'язку із передчасною смертю особи унаслідок злочинного порушення правил безпеки дорожнього руху або експлуатації транспорту. Економічний збиток визначасться як різниця між валовим внутрішнім продуктом та фактичним кінцевим споживанням у розрахунку на одну особу: S = B - C (84 $190-75627$ $=8563$ грн.). Отримана величина втрат множиться на кількість років, які у середньому не доживає жертва злочину (передбачених указаними вище кримінально-правовими нормами), тобто $t$ - t2 (71 - $40=31$ рік). Далі обраховуємо економічні втрати від смерті однієї особи: Втр $=(\mathrm{t}-\mathrm{t} 2) \mathrm{S}=31 * 8563=265453$ грн. Після чого отримуємо сумарну величину економічних втрат від смертей означених осіб у 2018 році: Всп = Втр $\mathrm{N}$ (265 453 грн. * $2150=570$ м.лн. 723 тис. грн.). І це дані тільки за один рік.

Чинне законодавство (Закони України «Про зайнятість населення», (Про прожитковий мінімум») послуговується терміном «працездатні особи» та відносить до їх числа осіб віком від 16 років, які проживають на території України, за станом здоров'я здатні до активної трудової діяльності й не досягли встановленого законом пенсійного віку. Право на пенсію за віком мають чоловіки - після досягнення 60 років і при стажі роботи не менше 25 років; жінки - після досягнення 55 років і при стажі роботи не менше 20 років (ст.12 3У «Про пенсійне забезпечення»). Кримінологічна характеристика автотранспортних злочинів підтверджує, що переважаючу частину потерпілих від вказаної протиправної поведінки становлять особи саме працездатного віку. Згідно отриманих автором результатів узагальнення вироків, про які мова йшла вище, кількість осіб працездатного віку, які загинули у результаті злочинів, передбачених ст.ст. 286, 135 КК України, становить $70 \%$, що можна віднести до числа негативних криміногенних наслідків у питанні збереження та відтворення життсвого потенціалу.

Слід відзначити, що судова практика розгляду справ про злочини, передбачені частинами 2 та 3 ст.286 КК України «Порушення правил безпеки дорожнього руху або експлуатації транспорту особами, які керують транспортними засобами», якщо вони спричинили смерть потерпілого чи загибель кількох осіб, налічує 
Медицкий І.Б.

непоодинокі випадки більш ніж лояльного ставлення до особи злочинця через застосування ст.75 КК України та подальшого їх звільнення від відбування покарання із встановленням іспитового строку. У 44\% проаналізованих автором випадків засуджені особи були звільнені від відбування покарання, з них: у 38\% випадків - на підставі ст.75 КК України, 6\% випадків - на підставі Закону України «Про амністію». Практиці відомі й випадки, коли від відбування покарання (як основного, так і додаткового - у виді позбавлення права на керування транспортним засобом), на підставі ст. 75 КК України звільняють особу, винну у загибелі 2-ох осіб (ч.3 ст.286 КК України). Існуюча тенденція, як видається, не співвідноситься із кримінологічною характеристикою, зокрема, (ціною) автотранспортних злочинів для суспільства та не досягає декларованої ст.50 KK України мети покарання - кари і запобігання вчинення нових злочинів як засудженими, так і іншими особами.

Згідно роз'яснень, викладених у пунктах 20, 21 Пленуму Верховного Суду України від 23.12.2005 р. №14 «Про практику застосування судами України законодавства у справах про деякі злочини проти безпеки дорожнього руху та експлуатації транспорту, а також про адміністративні правопорушення на транспорті», при призначенні покарання за відповідною частиною ст. 286 КК України, суди мають враховувати не тільки наслідки, що настали, а й характер та мотиви допущених особою порушень правил безпеки дорожнього руху або експлуатації транспорту, ії ставлення до цих порушень та поведінку після вчинення злочину, вину інших причетних до нього осіб (пішоходів, водіїв транспортних засобів, працівників, відповідальних за технічний стан і правильну експлуатацію останніх, тощо), а також обставини, які пом'якшують і обтяжують покарання, та особу винного. У кожному випадку призначення покарання за частинами 1 та 2 ст. 286 КК України необхідно обговорювати питання про доцільність застосування до винного додаткового покарання - позбавлення права керувати транспортними засобами або обіймати посади, пов'язані 3 відповідальністю за технічний стан чи експлуатацію транспортних засобів, відповідно. При винесенні обвинувальних вироків суди, в цілому, керуються вказаними роз'ясненнями, у абсолютній більшості справ (86\% із досліджених) приймаючи рішення 
про позбавлення особи права керувати транспортним засобом на той чи інший термін. 3 іншого боку, обгрунтовуючи рішення про наявність підстав для застосування означеного додаткового покарання, суди одночасно звільняють від його відбування на підставі ст.75 КК України, що є нелогічним та також не відповідає меті як загальної, так і спеціальної превенцій.

Висновки. 3 огляду на зазначене, кримінологічна та кримінально-правова політика протидії автотранспортним злочинам повинна відповідати вимогам своєчасності та повноти реагування, чому безумовно сприятиме отримання реальної інформації про їх кількісно-якісні негативні наслідки. Кримінологічно значуща інформація про наслідки автотранспортної злочинності характерна своєю неповнотою та фрагментарністю, не даючи уявлення про дійсну «ціну» цього різновиду для українського суспільства. Допускаємо, що у силу неповноти отримуваної інформації застосування судами окремих кримінально-правових норм про злочини проти безпеки руху та експлуатації транспорту не співвідноситься із декларованою КК України метою кари за вчинене, а також загальної і спеціальної превенції.

1. Безуглий A.O. Оцінка сочіально-економічних втрат від дорожньо-транспортних пригод. Управління проектами, системний аналіз i логістика. К.: HTУ. 2013. Bun. 12. C.231-238. URL: http:/irbis-nbuv. gov.ua/cgi-bin/opac/search.exe?C21COM $=2 \& I 21 D B N=U J R N \& P 21 D$ $B N=U J R N \& I M A G E$ FILE_DOWNLOAD=1\&Image_file_name $=P D F$ Upsal\% $5 F 2013 \% 5$ F 12\% 5 F28\%2Epdf (dama звернення: 23.11.2019)

2. Бабенко A.M. Запобігання злочинності в регіонах Украйни: концептуально-методологічний та праксеологічний вимір: монографія /A. M. Бабенко. Одеса: ОДУВС, 2014. $416 \mathrm{c}$.

3. Валовий внутрішній продукт у I-IV кварталах 2018 року й у 2018 poui. URL: http://www.ukrstat.gov.ualexpress/expr2019/03/38.pdf (dama звернення: 16.10.2019 р.)

4. Сдиний звім про заресстровані кримінальні правопорушення та результати їх досудового розслідування за 2013-2018 роки. URL: https:/www.gp.gov.ua/ua/statinfo.html (dama звернення: 02.08.2019)

5. Звіт судів периої інстанції про розгляд матеріалів кримінального провадження за 2014-2018 роки. URL: https:/court.gov.ua/inshe/ sudova_statystykal (dата звернення: 23.11.2019) 
Медицкий І.Б.

$\overline{\text { 6. Кондратюк Л.В., Овчинский В.С. Криминологическое измерение / Под }}$ ред. К.К. Горяинова /Л.В.Кондратюк, В.С.Овчинский. М., 2008. 272 с.

7. Медицький I.Б. Структурні елементи «ціни» злочинності у кримінологічній науці. Актуальні проблеми вдосконалення чинного законодавства України: Зб. наук. ст. м. Івано-Франківськ, Прикарпатський національний університет імені Василя Стефаника, 2018. Bun.47. C.169-177.

8. Підсумкова резолючія Периого міжнародного Конгресу з питань реформувания системи управліния безпеки дорожнього руху (2223 червня 2017 р., м. Kü̈в). URL: https:/www.ucci.org.ua/media/ filemanager/Resolution_16\%2006\%2017.pdf (дата звернення: 03.08.2019)

9. Скільки коштуе життя украӥнця в ДTП. URL: https:/life.pravda.com. ualhealth/2017/01/30/222337/(dama звернення: 03.08.2019)

10. Смерть на дорозі: шео приховус офіуійнастатистикапро ДТП в Украiнi. URL: https://www.epravda.com.ualpublications/2018/09/3/640036/ (дама звернення: 03.08.2019)

11. Cmamистика ДТП в Україні за 2017-2018 роки. URL: http:/patrol. police.gov.ua/statystyka/ (даma звернення: 02.08.2019)

12. Стратегія підвищення рівня безпеки дорожнього руху в Украйні на період до 2020 року: розпорядження КМ України від 14.06.2017 p. No481-p. URL: https://zakon.rada.gov.ua/laws/show/481-2017-p/print (дата звернення: 02.08.2019)

13. Таблиці народжуваності, смертності та середньої очікуваної тривалості життя за 2018 рік. Статистичний збірник. URL: http:// www.ukrstat.gov.ua/druk/publicat/kat_u/2019/zb/08/zb_tabl_nar_2018. pdf (dama звернення: 20.11.2019)

14. Украӥна повинна скоротити рівень смертності на дорогах ицонаймение вдвічі до 2020 року, - Володимир Омелян. URL: https://mtu.gov. ualnews/28788.html (дама звернення: 03.08.2019)

15. Цінавтрат, яким можназапобізти. ДТПв Україні. URL: https://d.ua macrolevel/cina-vtrat-yakim-mozhna-zapobigti-dtp-v-ukrayini-262072_. html (dama звернення: 03.08.2019)

Медищький І.Б. Гуманітарні та соціально-економічні наслідки автомобілізації в Україні: криміногенний аспект

У статті обгрунтовується необхідність обов'язкового урахування кримінологічної інформації про наслідки автотранспортних злочинів для підвищення ефективності кримінологічної та кримінально-правової політик протидії. Із використанням статистичної інформації судових і правоохоронних органів наведено характеристику потерпілих від кримінальних правопорушень у сфері безпеки 
Гуманітарні та соціально-економічні наслідки автомобілізації в Україні: криміногенний аспект

дорожнього руху та експлуатації транспорту, зазначено розмір матеріальної та моральної шкоди. У криміногенному контексті криміногенності здійснено аналіз гуманітарних та соціально-економічних наслідків автомобілізації в країні.

Ключові слова: наслідки злочинності, ціна злочинності, дорожнњо-транспортні пригоди, автомобілізація населення.

Медицкий И.Б. Гуманитарные и социально-экономические последствия автомобилизации в Украине: криминогенный аспект

В статье обосновывается необходимость обязательного учета криминологической информации о последствиях автотранспортных преступлений для повышения эффективности криминологической и уголовно-правовой политик противодействия. С использованием статистической информации судебньхх и правоохранительных органов приведена характеристика пострадавших от криминальных правонарушений в сфере безопасности дорожного движения и эксплуатации транспорта, указан размер материального и морального вреда. В криминогенном контексте осуществлен анализ гуманитарных и социально-экономических последствий автомобилизации в стране.

Ключевые слова: последствия преступности, цена преступности, дорожно-транспортные происшествия, автомобилизация населения.

Meditsky I.B. Humanitarian and socio-economic consequences of motorization in Ukraine: the criminogenic aspect

The article substantiates the necessity of obligatory consideration of criminological information on the consequences of motor crimes in order to increase the effectiveness of criminological and criminal legal policies. Criminologically relevant information on the consequences of motor vehicle crime is characterized by its incompleteness and fragmentation, without giving an idea of the true «price» of this variety for Ukrainian society. Through quantitative and qualitative analysis of the consequences of the phenomenon, the attention was paid to the scale and social danger of motor crime in modern conditions.

Based on the analysis of statistical information of the courts and law enforcement agencies over the past five years, the level of road traffic injuries is outlined, the dynamics compared to the previous year is revealed, the characteristics of the victims of criminal offenses in the field of road safety and transport operation are specified, the size of the caused material and moral damage. In the criminogenic context, an analysis of the humanitarian (the number of dead and injured as a result of road accidents) and the socio-economic consequences of motorization in the country (the cost of human life and the total losses from road accidents).

Existing approaches to determining the cost of human life and the overall level of losses to the state as a result of road accidents have been systematized. Taking into account the average life expectancy, macroeconomic indicators of the state development, the average age of those killed as a result of criminal violations of traffic safety rules or the operation of transport, and the number of victims, the total economic losses for the society for 2018 were determined.

It has been stated that the practice of application by the courts of separate criminal law rules on crimes against traffic safety and operation of transport does not correlate 
Микитин Ю.І.

with the declared Criminal Code of Ukraine for the purpose of punishment for the committed, as well as general and special prevention.

Keywords: consequences of crime, price of crime, road accidents, motorization of population.

Микитин Ю.І.

\section{ОСНОВИ ЄВРОПЕЙСЬКОÏ КРИМІНАЛЬНО- ПРОЦЕСУАЛЬНОЇ ПОЛІТИКИ У СФЕРІ КІБЕРПРАВОСУДДЯ}

УДК 343.137

https://doi.org/10.15330/apiclu.50.76-82

Постановка проблеми. Стрімкий розвиток інформаційних технологій охопив усі сфери людського життя. Початок їхнього активного використання простежується з 2000-чних років 3 метою підвищення ефективності функціонування судових систем європейських країн, зокрема, в межах кримінально-процесуальної діяльності. Значну роль у формуванні європейської кримінально-процесуальної політики у сфері кіберправосуддя відіграє Свропейська комісія з питань ефективності правосуддя Ради Свропи (CEPEJ).

Безумовно, акти цієї інституції мають значний вплив на формування національних кримінально-процесуальних політик і становлять науковий інтерес. Українські науковці погоджуються, що запровадження електронної форми кримінального провадження зумовлено розвитком сучасного суспільства та інформаційних технологій у світі та Україні та наголошують на необхідності удосконалення положень Кримінального процесуального кодексу України та інших законодавчих актів України, що регулюють відносини, пов'язані із запровадженням електронної форми кримінального провадження [1, с.51-52]. Крім того у науковій літературі звернуто увагу на перспективи запровадження міжнародного досвіду електронного кримінального провадження в Україні [2].

Виклад основного матеріалу. На формування європейської кримінально-процесуальної політики у сфері кіберправосуддя мали вплив Висновок Консультативної ради європейських суддів (ССJE) від 9 листопада 2011 р. №(2011)14 «Правосуддя та інфор- 